\title{
Homozygous familial hypercholesterolaemia in two sisters misdiagnosed as rheumatoid arthritis
}

\author{
Mahmoud H Ayesh (Haj Yousef), ${ }^{1}$ Ayham Shatnawi, ${ }^{2}$ Mai Khdeir, ${ }^{2}$ \\ Diala Khaldoon Alawneh ${ }^{2}$
}

'Department of Medicine, Jordan University of Science and Technology, Irbid, Jordan ${ }^{2}$ Jordan University of Science and Technology, Irbid, Jordan

\section{Correspondence to} Dr Mahmoud H Ayesh (Haj Yousef), ayeshmahmoud@hotmail.com

Accepted 6 October 2016
CrossMark

\section{To cite: Ayesh (Haj} Yousef) MH, Shatnawi A, Khdeir $\mathrm{M}_{\text {, et al. BMJ Case }}$ Rep Published online: [please include Day Month Year] doi:10.1136/bcr-2016216097

\section{DESCRIPTION}

A female patient aged 25 years and her younger sister aged 23 years were referred to the haematology clinic at our hospital suffering from irondeficiency anaemia. Before taking the medical history of the two patients, the older patient told the treating physician (the author) that she and her sister had been experiencing yellow swellings on their joints since they were 10 years of age. The patients were told that the cause of the swellings was rheumatoid arthritis (RA), but despite treatment for RA, the swellings increased in size. No related signs were observed among relatives, including the father and mother.

On physical examination, both sisters had xanthoma of the hands, elbows, knees and ankles (figures 1-3). Lipid profiles of both patients showed high cholesterol (22 and $23 \mathrm{mmol} / \mathrm{L}$ ) and low-density lipoprotein (LDL) levels (21 and $22 \mathrm{mmol} / \mathrm{L})$, and normal levels of triglyceride $(1.36$ and $1.46 \mathrm{mmol} / \mathrm{L})$ and HDL $(0.8$ and $0.85 \mathrm{mmol} /$ L), respectively. The father and mother had high cholesterol (10.54 and $9.23 \mathrm{mmol} / \mathrm{L})$ and $\mathrm{LDL}$ (8.1 and $6.7 \mathrm{mmol} / \mathrm{L}$ ) levels, respectively, consistent with heterozygous familial hypercholesterolaemia $(\mathrm{HeFH})$. We found parents to be first cousins.

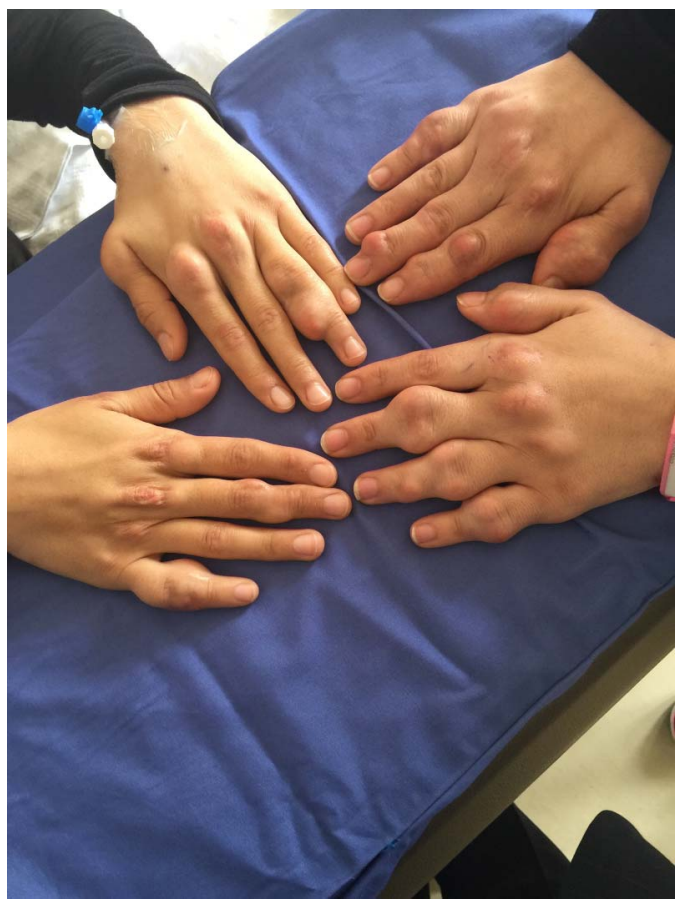

Figure 1 Tendon xanthoma involving the hands of both patients.

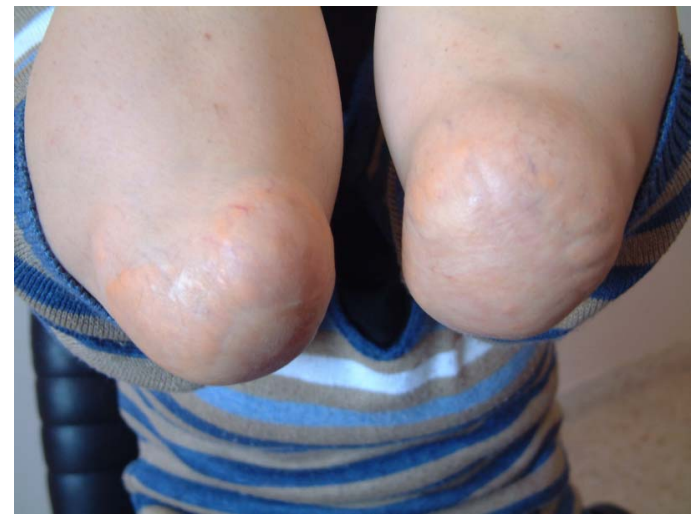

Figure 2 Tuberous xanthoma of the elbows of the younger sister.

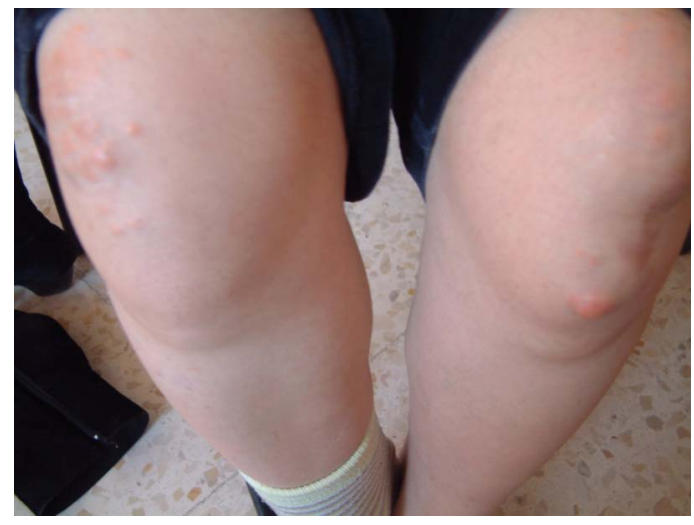

Figure 3 Tuberous xanthoma of the knees of the younger sister.

A diagnosis of homozygous familial hypercholesterolaemia $(\mathrm{HoFH})$ was made based on early age onset of xanthomas with high LDL levels, supported by $\mathrm{HeFH}$ diagnosis in both parents. No molecular studies were available. ${ }^{1}$

$\mathrm{HoFH}$, a rare genetic disorder with a frequency of $1: 300000$ to $1: 1000000$, is characterised by premature accelerated atherosclerosis of the cardiovascular system that affects the aortic root and the coronary ostia. In young patients, early symptoms and signs are associated with aortic stenosis and regurgitation. Treatment options for $\mathrm{HoFH}$ include lifestyle modifications, the administration of lipid-lowering medications, such as statins, and LDL aphaeresis. Recently, lomitapide and PCSK9 monoclonal antibody inhibitors have been used. ${ }^{1}$ 


\section{Learning points}

- Homozygous familial hypercholesterolaemia (HoFH) is characterised by high plasma low-density lipoprotein levels and xanthomas before 10 years of age. It can be misdiagnosed as rheumatoid arthritis.

- HoFH is an important risk factor for premature coronary artery and atherosclerosis disease in children and young adults.

- HoFH early symptoms and signs are often associated with aortic valve-related disease in young patients.
Contributors MHA worked up the case and wrote the case report. AS, MK and DKA reviewed the case report.

Competing interests None declared.

Patient consent Obtained.

Provenance and peer review Not commissioned; externally peer reviewed.

\section{REFERENCE}

1 Cuchel M, Bruckert E, Ginsberg HN, et al. Homozygous familial hypercholesterolaemia: new insights and guidance for clinicians to improve detection and clinical management. A position paper from the Consensus Panel on Familial Hypercholesterolaemia of the European Atherosclerosis Society. Eur Heart J 2014;35:2146-57.

Copyright 2016 BMJ Publishing Group. All rights reserved. For permission to reuse any of this content visit http://group.bmj.com/group/rights-licensing/permissions.

BMJ Case Report Fellows may re-use this article for personal use and teaching without any further permission.

Become a Fellow of BMJ Case Reports today and you can:

- Submit as many cases as you like

- Enjoy fast sympathetic peer review and rapid publication of accepted articles

- Access all the published articles

- Re-use any of the published material for personal use and teaching without further permission

For information on Institutional Fellowships contact consortiasales@bmjgroup.com

Visit casereports.bmj.com for more articles like this and to become a Fellow 